\title{
Proposals for Mental Health in Italy at the End of the Nineteenth Century: between Utopia and Anticipating the "Basaglia Law"
}

\author{
Vincenzo Bongiorno*
}

Department of Education, Psychology, Philosophy, University of Cagliari, Italy

\begin{abstract}
The present work refers to the debate which took place in Italy in the final years of the nineteenth century in relation to mental health and lunatic asylums, from which emerged various innovative proposals for avoiding compulsory confinement in numerous cases. Some of them became part of new legislative regulations regarding asylums, but most were excluded. Today, a new historical interpretation allows us to grasp a connection between Law 180, dated 1978 and known as the "Basaglia Law" from the name of its promoter, and alternative proposals to asylum custody omitted from the 1904 law.
\end{abstract}

Keywords: Asylum, Curability, History of Psychiatry, Mental Health, Training.

\section{INTRODUCTION}

This work refers to the debate taking place in Italy during the final decades of the nineteenth century, regarding mental health and lunatic asylums which housed an ever-increasing number of patients suffering from mental illness. Overcrowding, lunatic asylums, coercive and inhuman methods, the degradation in which patients lived, medical and administrative difficulties and various deficiencies indeed called for innovative, urgent proposals.

In this paper, we will mention some of the solutions proposed at the end of the nineteenth century which foresaw the establishment of new asylums and the renovation of existing ones, but also and above all the following alternatives: a) the placing of incurable, harmless chronic patients in homes and hospices; b) family homes; c) confinement in the home; d) charitable institutions for poor, discharged, cured or convalescent mental patients.

These new contexts would have favored life experiences and relationships in a natural family environment, from which patients had been alienated, and above all revived "the sense of human dignity" indispensable for the therapeutic process. Equally important was to have been the training of doctors and above all nurses by means of specialized schools and the re-establishment of humane relationships between doctors and patients. Experiences involving solutions of this type, already existing in other European countries were also carried out in Italy due to the goodwill of Asylum doctors and superintendents who fostered international relationships. However, their proposals were not fully incorporated into the 1904 law on asylums and thus not put into practice [1]. Setting them aside had a negative influence on psychiatric

*Address correspondence to this author at the Department of Education, Psychology, Philosophy, University of Cagliari, Via Is Mirrionis 1, 09123 Cagliari, Italy; Tel +390706757332; Fax: +390706753825;

E-mail: vbongior@unica.it treatment in Italy and consequently fuelled the debate that 70 years later concluded with the enactment in 1978 of Law 180 , commonly known as the "Basaglia Law".

Law 180 is the result of ideas inspired by the struggles of "anti-psychiatry", "new psychiatry", "democratic psychiatry", etc. and by experiences in various asylums, prevalently linked to the figure and role of $\mathrm{F}$. Basaglia. According to dominant Marxist ideology, some authors reduced mental illness to a product of society or "repression" or a commitment on the part of society to socialize with patients. From the viewpoint of democratic psychiatry, mental illness were denied in its existence or were completely reduced to the target of "organic" treatment using psychotropic drugs [2].

In order to avoid a referendum, the hasty approval of the law does not take into account the well-constructed debate on reform, with consequences on a theoretical and practical level (see Ossicini [3] in his meticulous re-examination). Indeed, if there was general consensus on closing asylums and Ossicini himself had already proposed it in 1944 [4], on the other hand, reflection on the complexity of medical, psychological, social and political responses to mental illness continued.

Law 180, dismantling asylums and the treatment carried out within them, shifted attention toward the surrounding territory and alternative structures, overturning the terms of the problem in respect to the past, almost as if accepting some of the alternatives in the 1904 law.

We believe we can link the broadest needs underlying the law, stripped of their ideological distortions, to the "spirit" of the proposals not ultimately included in the 1904 law which, in the light of experience in some asylums, above all in Reggio Emilia, conceived of the asylum as a "transitory" place for "acute cases"; having overcome this "acute stage", other appropriate structures could take in chronically-ill mental patients and those on the road to recovery, using adequate therapeutic tools and respecting their dignity. 
These two outlooks differ historically, although we believe that some of the most profound arguments underlying the debate on Law 180, which still persist, may be linked to unresolved problems regarding mental health at the beginning of the twentieth century.

The literature on this subject is clearly extremely vast and, therefore, in this study, we have selected and closely examined only those parts focusing on this subject during the final years of the nineteenth century.

\section{PSYCHIATRIC MADNESS AND SOCIETY IN NINE- TEENTH-CENTURY ITALY}

With the progress in psychiatric knowledge during the last three decades of the nineteenth century in Italy, as well, a debate had developed on how to treat the suffering, deviant humanity which, isolated in the course of centuries, had found hospitality in various structures which finally were transformed into asylums. The response to that distinctive expression of social deviance recognized as madness had been divided, on a theoretical level, in the attempt to scientifically interpret mental suffering in an anatomicalbiological sense and on a practical level, reflecting on the value and limits of the asylum as an institution, a sophisticated therapeutic tool but at the same time segregating. It was thus made concrete with psychiatry as a science on the one hand and the asylum as a practical social solution on the other [5-7].

The development of psychiatric thinking and the interpretative paradigms of deviance phenomena went hand in hand with the debate on asylums, viewed as the answer to a problem that was considered of a prevalently social nature. It regarded the identification and classification of mental illness and at the same time the methods of treating it.

In this process, the operation that attempted, on a scientific level, to transform patients into clinical cases, victims in terms of a neutral, abstract classification of mental illness, exclusively understood as physiological degeneration, was linked to reconstructing the real identity of the variegated crowd populating asylums at the end of the nineteenth century [8-10]. Mental illness and the cultural and social environment in which it was manifested, responses arising from society starting from asylums and the development of psychiatry as a science thus made up the framework within which, in the last three decades of the nineteenth century, a debate went on in Italy, directed towards passing legislation setting this sector in order.

To put this in context, statistical research should be inserted which attempts to determine the state of asylums in Italy starting in 1871 [11]. Obviously, with the increase in patients, relative expenses rose exponentially, raising the question of how to solve this problem.

\section{PROPOSALS FOR SOLVING EMERGING PROBLEMS}

Proposed solutions took several directions. The first regarded the establishment of new asylums or the enlarging and renovation of existing ones. Others alternatively suggested, as mentioned above, solutions of various types in homes, hospices, family structures, home custody or charitable institutions.
All these solutions were based on a radical change in the concept of asylum dominant at that time. It was indeed necessary to affirm the idea of the asylum as a space primarily entrusted with a therapeutic function, with "treating acute mental illnesses", rather than a space to neutralize the dangerousness of patients, as it had been considered up to that time. This was a radical change in perspective, denying the binomial: madness $=$ dangerousness, but also the equation: madness $=$ mental illness $=$ incurability. In conformity with the new paradigm, the logic to be followed was the one according to which "mental illness is an illness that can be treated like any other, especially an acute one", thus curable in many cases. Only as a last resort was the asylum to be considered the mere response to danger, the concept that had previously predominated $[12,13]$.

Future psychiatric reform was thus to be inspired, on a legislative level, by the paradigm according to which:

1. the true purpose of the asylum was to be a place, not of simple segregation and personal custody, but of efficient treatment for the mentally ill in the acute phase, "carried out in a rational and above all individual way, the same way in which common illnesses were treated in hospitals";

2. the increasing and inevitable costs sustained by Provinces for maintaining the insane were to be better employed to the advantage of the patients themselves, with modern, functional organizational reforms;

3. the number of patients in asylums had to respect the hygienic and technical standards of the individual institutions.

To carry out this project, it was necessary to

a. establish new asylums intended only to treat recent, acute, curable cases and create in preexisting ones separate sections for the same type of insanity, supplying them with all necessary resources.

b. discharge from asylums all patients not belonging to these categories, to solve the problem of overcrowding and avoid a prolonged stay from becoming a factor of chronicity and incurability in mental illnesses.

The patients involved in this reorganization were:

a. idiots and imbeciles not exhibiting dangerous tendencies;

b. the incurable, chronically insane (of any type) but calm and identified as harmless.

c. elderly, weak or infirm patients suffering from common chronic illnesses and permanently bedridden;

d. pellagrins who, after cessation of their mental disturbance, were often detained in the asylum due to risk of relapse and who, if discharged, returned to their previous alimentary habits;

e. alcoholics, perfectly normal if kept away from alcohol, but who easily relapsed after the slightest abuse;

f. epileptics without other pathological manifestations except for convulsions.

For most of them, the solutions proposed regarded the establishment of special shelters, appropriate placement of the 
chronically insane, care in the home and charitable institutions, according to the program:

1. of placing chronic, incurable and harmless patients in special homes and hospices, dedicating special sections to them or adapting old asylum buildings, thus reducing costs and reducing treatment to the essentials;

2. of encouraging and developing family charitable institutions both for the harmless chronically insane and for idiots and other patients, that is encouraging their care in the home with subsidies provided by the Province under the supervision of the asylum superintendent and doctors;

3. of encouraging and actively developing public charity, charitable institutions for the poor, discharged, cured or convalescent mentally ill, especially pellagrins, recurrent cases, etc., offering consistent, long-term subsidies, to avoid inevitable relapses when going back to living in wretched conditions.

These measures, presented for general psychiatric reform had already been put into practice in some places in Tuscany, the Provinces around Bergamo, Modena, and in particular in the Reggio Emilia Asylum, which could boast of being a pioneer. On the other hand, they mirrored experiences abroad, as in Scotland, France, Germany, Russia, The Netherlands and Switzerland, but the reference point was above all Belgium, with its classical model of the Gheel Home [14].

\section{THE TRAINING OF NURSING STAFF}

Having regained the concept of the asylum as solely a place for treatment of the acute stage, attention was extended to the problem of training medical and nursing staff. Therefore, a training school was necessary which, by means of theoretical lessons and practical training, would convey the special knowledge and competence required and favor the development of conscientiousness on a level with the tasks entrusted to them.

Schools of this type were springing up in England and in France, but the most highly qualified ones for treating the insane were in The Netherlands, managed by the asylum superintendents and doctors, in particular in the Meerenberg Asylum, where the role of the so-called "lay sisters" was established. They were in charge, as supervisors, of the nursing service and treatment of patients and cooperated with doctors [15-17].

In Italy, to train nurses for asylums, in 1903 A. Tamburini initiated the first regular technical-professional course with the help of nurses themselves in the Reggio Emilia Asylum. Among the requisites for admission was the ability to read and write correctly, not to be addicted to alcoholic beverages and to be free from hereditary defects and mental and nervous illnesses. Courses were of a theoretical-practical nature and included elementary notions of anatomy, physiology, bodily hygiene, mental functions and their principal alterations and their physical and moral causes. In addition, there were theoretical and practical rudiments on examining the patient and on assisting in care and in physical and moral treatment, notions on emergency assistance and medications and, finally, knowledge of laws and relative regulations [18].
Intervention policy was inspired by a humanitarian approach whose objective was to establish authentic human relationships and substitute the coercive treatment of the past which, no longer the rule, becomes absolutely exceptional, recognized as such solely by the mental specialist. This, was to avoid risks to health and the psyche of the patient, but above all to respect and promote his personal dignity. In the implementation of this principle, not an easy task, doctors could obtain valid assistance from nurses who had been trained professionally and humanely.

\section{CONCLUSIONS}

We believe that the historical lines we have considered permit interpretation of the current debate on psychiatric care in another light, that is pointing out what has been done, what has been neglected but above all the fundamental principle which must guide every human and professional approach to the abyss of madness: the principle of the dignity of each individual [19]. In this sense, we would like to conclude by recalling how these guidelines were reproposed and emphatically affirmed in the early 1900's by the American C.W. Beers, who, having been interned in an American asylum, as soon as he was discharged, published his autobiography in 1908 in the book A Mind that Found Itself. An Autobiography [20], thus founding the Movement for Mental Hygiene on an international level and marking a radical turning-point in this sector.

\section{CONFLICT OF INTEREST}

The authors confirm that this article content has no conflicts of interest.

\section{ACKNOWLEDGEMENTS}

Declared none.

\section{REFERENCES}

[1] Tamburini A. La Legge sui Manicomi [The Law for Lunatic Asylums]. Riv Sperim di Freniatr 1904; 30: 220-41.

[2] Jervis G. Manuale critico di psichiatria [Critical Manual of Psychiatry. $3^{\text {rd }}$ ed. Milano: Feltrinelli 1991; pp. 101-41.

[3] Ossicini A. La rivoluzione della psicologia The Revolution of Psychology. Roma: Borla 2002; pp. 90-106; 221-39.

[4] Ossicini A. La rivoluzione della psicologia The Revolution of Psychology]. Roma: Borla 2002; pp. 104-6.

[5] Bergomi M, Bonilauri F, Dall'Acqua M, et al. Il cerchio del contagio. Il San Lazzaro tra lebbra, povertà e follia (1178-1980) [The Circle of the Contagion. The San Lazzaro between Leprosy, Poverty and Madness (1178-1980)]. Reggio Emilia: Istituti ospedalieri neuropsichiatrici 1980; pp. 15-54.

[6] Bongiorno V. Nuove istanze e aperture nella Psichiatria italiana del primo Novecento [New Solicitations and Perspectives in Italian Psychiatry in the Early Twentieth Century]. Arch Psicol Neurol Psichiatr. 1989; 50(2): 193-97.

[7] Bongiorno V. Il dedalo della mente. Augusto Tamburini tra neurofisiologia e psichiatria [The Maze of the Mind: Augusto Tamburini between Neurophysiology and Psychiatry]. Roma: Edizioni Kappa 2002; pp. 27-75.

[8] Bongiorno V. The "Project of Experimental Psychology" Developed in Italy by neurophysiologists and psychiatrists. Physis 2006; 43: 387-405.

[9] De Bernardi A. Malattia mentale e trasformazionoi sociali. La storia dei folli [Mental Illness and Social Transformations. A History of the Insane]. In: De Bernardi A, Ed. Follia Psichiatria e Società. Milano: Franco Angeli 1980; pp. 11-32.

[10] Tasca C, Rapetti M, Carta MG, et al. Women and hysteria in the history of mental health. Clinical practice and epidemiology in mental health: Clin Pract Epidemiol Ment Health 2012; 8: 110-9. 
[11] Tamburini A. Discorso inaugurale al X Congresso della Società freniatrica italiana. (Napoli, 10-14 ottobre 1899) [Inaugural Address at the $\mathrm{X}$ Congress of the Italian Psychiatric Society. Naples October 10-14, 1899)]. Riv Sperim Freniatr 1900; 26: 74957.

[12] Tamburini A, Fornasari di Verce E. Le condizioni dei manicomi e degli alienati in Italia (1896-1899) [The Conditions of Asylums and the Insane in Italy (1896-1899)]. Riv Sperim Freniatr 1900; 26(23): 487-505.

[13] Ferrari GC. Come si può impiantare ed organizzare in Italia una Colonia familiare per alienati [How to Establish and Organize a Family Colony for the Mentally Ill in Italy]. Riv Sperim Freniatr 1903; 29: 324-45.

[14] Tamburini A. Sulle attuali condizioni dei Manicomi e degli alienati in Italia [On the Present Conditions of Asylums and the Insane in Italy]. Riv Sperim di Freniatr Reggio Emilia: Tip. Stef. Calderini e Figlio 1897; pp. 3-14.
[15] Ferrari GC. Le scuole per infermieri di Manicomio [Schools for Asylum Nurses]. Riv Sperim Freniatr 1897; 23: 714-5.

[16] Ferrari GC. L'istruzione tecnica professionale per gli infermieri [Technical Professional Education for Nurses]. Riv Sperim Freniatr 1902; 28: 729-34.

[17] Tamburini A. Per l'inaugurazione del $2^{\circ}$ Corso d'Insegnamento professionale degli infermieri del Manicomio di Reggio [On the Inauguration of the $2^{\circ}$ Professional Course for Nurses in the Reggio Asylum]. Riv Sperim Freniatr 1904; 30: 3-13.

[18] Tamburini A. Per l'Inaugurazione del II anno d'Insegnamento professionale degli infermieri nel Frenocomio di Reggio [On the Inauguration of the II Year Professional Course for Nurses in the Reggio Asylum]. Riv Sperim Freniatr 1905; 31: 1-10.

[19] Carta MG, Agaj A, Harapej E, et al. Outcomes of discharged females versus those waiting for discharge from Vlore Psychiatric Hospital (Albania). Int J Soc Psychiatry 2013; 59: 682.

[20] Beers CW. A Mind that found Itself. An Autobiography. London and New York: Longmans 1908.

(C) Vincenzo Bongiorno; Licensee Bentham Open.

This is an open access article licensed under the terms of the Creative Commons Attribution Non-Commercial License (http://creativecommons.org/licenses/by-nc/3.0/) which permits unrestricted, non-commercial use, distribution and reproduction in any medium, provided the work is properly cited. 